\title{
Exhaled nitric oxide predicts lung function decline in difficult-to-treat asthma
}

\author{
I.H. van Veen*, A. ten Brinke ${ }^{\#}$, P.J. Sterk ${ }^{\uparrow,+}$, J.K. Sont ${ }^{\S}$, S.A. Gauw ${ }^{\top}$, \\ K.F. Rabe ${ }^{\oplus}$ and E.H. Bel
}

ABSTRACT: A subset of patients with asthma is known to have progressive loss of lung function despite treatment with corticosteroids. The aim of the present study was to identify risk factors of decline in forced expiratory volume in one second (FEV1) in patients with difficult-to-treat asthma.

In total, 136 nonsmoking patients with difficult-to-treat asthma were recruited between 1998 and 1999. Follow-up assessment was performed 5-6 yrs later in 98 patients. The predictive effect of clinical characteristics and inflammatory markers were analysed at baseline (asthma onset and duration, atopy, airway hyperresponsiveness, blood and sputum eosinophils, and the fraction of nitric oxide in exhaled air ( $\mathrm{FeNO})$ ) on subsequent decline in post-bronchodilator FEV1.

Patients with high FeNO ( $\geqslant 20 \mathrm{ppb}$ ) had an excess decline of 40.3 (95\% confidence interval (Cl) 7.3-73.2) $\mathrm{mL} \cdot \mathrm{yr}^{-1}$ compared to patients with low FeNO. FeNO $\geqslant 20 \mathrm{ppb}$ was associated with a relative risk of $1.9(95 \% \mathrm{Cl}, 1.1-2.6)$ of having an accelerated $\left(\geqslant 25 \mathrm{~mL}^{-y^{-1}}\right)$ decline in $\mathrm{FEV}_{1}$. In patients with baseline $\mathrm{FEV}_{1} \geqslant 80 \%$ of predicted, this relationship was even stronger: 90 versus $29 \%$ had accelerated decline in $\mathrm{FEV}_{1}$ ( $\mathrm{FeNO}_{2} \geqslant 20 \mathrm{ppb}$ versus $\mathrm{FeNO}<\mathbf{2 0} \mathrm{ppb}$ respectively; relative risk 3.1 (95\% Cl, 1.7-3.4).

Exhaled nitric oxide is a predictor of accelerated decline in lung function in patients with difficult-to-treat asthma, particularly if forced expiratory volume in one second is still normal.

KEYWORDS: Airway obstruction, asthma, nitric oxide, severity of illness index

$\mathrm{n}$ the majority of patients, asthma can be controlled with inhaled corticosteroids, which are the cornerstone of treatment for asthma. However, $\sim 5-10 \%$ of all asthma patients are refractory to even high doses of inhaled or oral corticosteroid therapy [1], and may develop persistent airway obstruction over the years [2, 3], which has been associated with increased morbidity and mortality [4]. Therefore, it is of critical importance to identify patients who are less responsive to steroid treatment and are at risk of developing persistent airway obstruction at an early stage. These patients should be closely monitored and considered for novel anti-asthma drugs in order to prevent progression of their disease [5].

Persistent airway obstruction in asthma is believed to be a consequence of structural and functional changes in the airways [6], possibly related to abnormal injury and repair responses of the bronchial epithelium, which are either inherited or acquired [7]. Genetic [7] and environmental factors [2] have indeed been associated with an accelerated decline in lung function in asthma.

Recent evidence suggests that airway inflammation per se may be an important contributor to progressive loss of lung function. In longitudinal studies, accelerated decline in forced expiratory volume in one second (FEV1) has been associated with severe asthma exacerbations [8] and CD8positive T-cells in bronchial biopsies [9]. Crosssectional studies in severe asthma have shown associations between persistent airway obstruction and eosinophilia in blood [10], sputum [3] and bronchial biopsies [11].

The aim of the present study was to assess the rate of lung function decline and identify the risk factors of accelerated decline in patients with difficult-totreat asthma. In total, 136 nonsmoking adults with difficult-to-treat asthma were recruited between 1998 and 1999 to participate in a study aimed at identifying different clinical phenotypes of asthma and risk factors of accelerated decline in lung function $[3,12,13]$. This group of patients was reassessed 5-6 yrs later. Potential risk factors, including patients' clinical characteristics (age of asthma onset, duration of asthma, atopy and airway hyperresponsiveness), and three different noninvasive markers of airway inflammation (eosinophils in peripheral blood and induced sputum, and the fraction of nitric oxide in exhaled air $(\mathrm{FeNO}))$ were assessed at baseline and related to the change in lung function over time.

\section{AFFILIATIONS}

Dept of *Pulmonology, Medisch

Spectrum Twente, Enschede,

\#Dept of Pulmonology, Medical

Center Leeuwarden, Leeuwarden, Depts of "Pulmonology,

${ }^{\S}$ Medical Decision Making, Leiden

University Medical Center, Leiden, and

+Dept of Respiratory Medicine,

Academic Medical Center,

Amsterdam, The Netherlands.

\section{CORRESPONDENCE}

I.H. van Veen

Dept of Pulmonology

Medisch Spectrum Twente

Postbus 50000

7500 KA Enschede

The Netherlands

Fax: 31534872638

E-mail: h.vanveen@ziekenhuis-

mst.nl

Received:

October 152007

Accepted after revision:

May 072008

STATEMENT OF INTEREST

Statements of interest for I.H. van Veen, P.J. Sterk, S.A. Gauw and K.F. Rabe can be found at www.erj.ersjournals.com/misc/ statements.shtml 


\section{METHODS}

\section{Subjects}

Between 1998 and 1999, 136 patients with difficult-to-treat asthma were recruited to participate in the study $[3,12,13]$. Pulmonologists from two teaching and eight nonteaching hospitals in the Netherlands were asked to identify nonsmoking patients with difficult-to-treat asthma from their outpatient clinic. In total, 152 patients were approached by the study coordinator by telephone and asked to participate. Of these, 16 patients refused to participate, mainly for reasons of lack of transport or time.

Patients had to fulfil the criteria for "difficult/therapy-resistant asthma" as defined by a European Respiratory Society Task Force [14]. All patients had a history of episodic dyspnoea and wheezing, a documented reversibility in FEV1 of $>12 \%$ of the predicted value or airway hyperresponsiveness to inhaled histamine. The patients were treated with high doses of inhaled corticosteroids $\left(\geqslant 1,600 \mu \mathrm{g} \cdot \mathrm{day}^{-1}\right.$ of beclomethasone or equivalent) combined with long-acting bronchodilators for $>1$ yr. All patients were symptomatic and had at least one severe exacerbation during the past year requiring a course of oral corticosteroids, or were receiving chronic oral corticosteroid therapy. The maximum smoking history permitted was 10 pack-yrs.

Patients were reassessed to determine the change in lung function over time 5-6 yrs later. Patients had to be clinically stable without asthma exacerbations for $\geqslant 1$ month before their laboratory visits. Assessment visits were postponed when patients were prescribed prednisone courses or antibiotic treatment for asthma exacerbations in the month prior to the visit.

The cross-sectional results of the present study have been previously described $[3,13]$. The study was approved by the Ethics Committee of the Leiden University Medical Center (Leiden, the Netherlands) and all other participating hospitals. All patients gave written informed consent.

\section{Design}

Patients underwent an extensive assessment protocol in 1998 or 1999. Patient characteristics (age, sex, atopic status, age of asthma onset and asthma duration), lung function (pre- and post-bronchodilator FEV1, inspiratory vital capacity (IVC), airway hyperresponsiveness, lung volumes and diffusion capacity), FeNO and eosinophils in peripheral blood and induced sputum were measured. A computed tomography scan of the paranasal sinuses and a 24-h $\mathrm{pH}$ measurement of the oesophagus were performed, and psychological questionnaires were completed. The results of these tests (with the exception of sputum eosinophils and $F$ eNO) were reported to the individual chest physician of each patient, who, if necessary, initiated treatment for previously unidentified aggravating or comorbid factors. The patients were closely monitored and treated by their own chest physician between 1998/1999 and 2004/2005. In 2004/2005, a short medical history was taken and spirometry was performed before and after maximal bronchodilation. The same lung function equipment and standardised methods as those at baseline were used.

\section{Measurements}

History taking

All patients underwent a structured case history in order to assess patient characteristics, including severity of symptoms, medication usage and duration of asthma [3]. The latter was estimated from the first-ever attack of dyspnoea or wheezing.

\section{Atopic status and peripheral blood eosinophils}

Atopic status was assessed on a score of $0-4$ by specific immunoglobulin $\mathrm{E}$ to a panel of common aero-allergens (UniCAP; Pharmacia and Upjohn, Uppsala, Sweden). Eosinophils in blood were measured by a standard automated cell counter.

\section{FeNO in exhaled air}

FeNO measurements were performed according to a standardised method [15], using a chemiluminescence analyser (Sievers NOA 270B; Sievers, Boulder, CO, USA). After inhaling "NO-free" air (<2 ppb) from residual volume to total lung capacity, subjects performed a slow expiratory vital capacity manoeuvre with a constant expiratory flow rate of $100 \mathrm{~mL} \cdot \mathrm{s}^{-1}$ (standard at the time of study initiation). Plateau levels of FeNO against time were determined and expressed as ppb.

\section{Spirometry and histamine provocation testing}

FEV1 and slow IVC measurements were performed before and $30 \mathrm{~min}$ after inhalation of $400 \mu \mathrm{g}$ salbutamol and $80 \mu \mathrm{g}$ ipratropium bromide through a volume spacer, according to standard methods. Predicted values of FEV1 and IVC were obtained from a previous study [16].

The annual decline in lung function was calculated in $\mathrm{mL} \cdot \mathrm{yr}^{-1}$ by subtracting the $2004 / 2005$ post-bronchodilator FEV1 from the 1998/1999 post-bronchodilator FEV1. Post-bronchodilator FEV1 was chosen rather than pre-bronchodilator FEV1 to avoid the influence of variable smooth muscle contraction in the assessment of FEV1 decline.

Airway responsiveness to histamine, expressed as the provocative concentration causing a $20 \%$ fall in FEV1 (PC20 histamine) was measured using the standard tidal breathing method [17].

\section{Sputum}

Sputum was induced and processed according to a validated protocol [18], using the full sample method. Normal saline solutions were inhaled three times for $5 \mathrm{~min}$ with frequent monitoring of FEV1.

\section{Analysis}

Linear regression was used to analyse the association between potential predicting factors and decline in FEV1 $\left(\mathrm{mL} \cdot \mathrm{yr}^{-1}\right)$. Baseline FEV1 was included in the analysis as a covariate. FeNO, sputum and blood eosinophils, and PC20 histamine were log-transformed before analysis to achieve a normal distribution of data. Results were expressed as slope of the regression line (B) with 95\% confidence interval (CI), which indicates the increase in the dependent variable per one unit increase in the independent variable.

Potential predicting and modifying factors were analysed both as continuous and dichotomous independent variables, using the following contrasts: age of asthma onset $\geqslant 15$ versus $<15 \mathrm{yr}$ 


\begin{tabular}{|c|c|c|c|}
\hline \multirow[t]{2}{*}{ TABLE 1} & \multicolumn{3}{|c|}{$\begin{array}{l}\text { Baseline characteristics of } 98 \text { study participants } \\
\text { and } 38 \text { nonparticipants }\end{array}$} \\
\hline & & Participants ${ }^{\#}$ & Nonparticipants \\
\hline Age yr & & $45.1 \pm 13.1$ & $46.2 \pm 17.2$ \\
\hline Females & & 68 & 74 \\
\hline Age of asth & la onset yrs & $14.5(0.5-68)$ & $18.0(0.5-65)$ \\
\hline Duration of & sthma yrs & $18.5(2-63)$ & $17.0(2-73)$ \\
\hline Inhaled ster & ids $\mu \mathrm{g} \cdot \mathrm{day}^{-1}$ & $1600(1600-4800)$ & $1600(1600-6400)$ \\
\hline Chronic ora & steroids & 30 & 41 \\
\hline Atopy & & 61 & 51 \\
\hline Post-bronch & dilator $\mathrm{FEV}_{1} \%$ pred & $78.6 \pm 24.9$ & $76.9 \pm 22.8$ \\
\hline PC20 histam & ne $\mathrm{mg} \cdot \mathrm{mL}^{-1}$ & $1.1(0.02-8)$ & $3.6(0.02-8)$ \\
\hline Blood eosin & phils $\times 10^{9}$ & $0.18(0.01-1.35)$ & $0.22(0.02-1.29)$ \\
\hline Sputum eos & tophils \% & $1.8(0-59.4)$ & $0.8(0-54.5)$ \\
\hline FeNO ppb & & $9.6(2-123.8)$ & $9.1(2-202.3)$ \\
\hline \multicolumn{4}{|c|}{$\begin{array}{l}\text { Data are presented as mean } \pm \mathrm{SD} \text {, per cent or median (range). } \mathrm{FEV} 1 \text { : forced } \\
\text { expiratory volume in one second; \% pred: \% predicted; } \mathrm{PC}_{20} \text { : provocative dose } \\
\text { causing a } 20 \% \text { fall in } \mathrm{FEV} \text {; } F \text { eNO: the fraction of nitric oxide in exhaled air. } \\
\text { \#: airway hyperresponsiveness to histamine, peripheral blood eosinophils, } \\
\text { sputum eosinophils and } F \text { eNO could be measured in } 47,90,54 \text { and } 71 \text { patients, } \\
\text { respectively. }\end{array}$} \\
\hline
\end{tabular}

(median for whole group); asthma duration $\geqslant 18$ versus $<18$ yr (median for whole group); atopic versus nonatopic; PC20 histamine $\leqslant 1.0$ versus $>1 \mathrm{mg} \cdot \mathrm{mL}^{-1}$ [19]; eosinophils in peripheral blood $>0.45$ versus $\leqslant 0.45 \times 10^{9} \cdot \mathrm{L}^{-1}$ (normal value of local laboratory); baseline FEV1 $\geqslant 80$ versus $<80 \%$ pred (median value for the whole group); eosinophils in induced sputum $\geqslant 2$ versus $<2 \%$ [20]; and FeNO $\geqslant 20$ versus $<20 \mathrm{ppb}$. The latter values were based on receiver operating characteristic (ROC) analysis. This analysis was used to find a cut-off value for FeNO that would identify patients with an accelerated decline in lung function $\left(\geqslant 25 \mathrm{~mL} \cdot \mathrm{yr}^{-1}\right)$. A cut-off point for FeNO with a high specificity of the test was favoured. This analysis showed that an FeNO level of 19.1 was associated with a sensitivity of 0.48 and a specificity of 0.80 , whereas an FeNO level of 21.9 was associated with a sensitivity of 0.44 and a specificity of 0.82 (area under the curve 0.64 ). Consequently, an FeNO value of $20 \mathrm{ppb}$ was chosen. A value of $20 \mathrm{ppb}$ at $100 \mathrm{~mL} \cdot \mathrm{s}^{-1}$ corresponds to $\sim 35 \mathrm{ppb}$ at $50 \mathrm{~mL} \cdot \mathrm{s}^{-1}$ [21].

Logistic regression was used to estimate odds ratios (ORs) with $95 \%$ CIs for accelerated decline in FEV1, defined as $\geqslant 25 \mathrm{~mL} \cdot \mathrm{yr}^{-1}$. A decline in $\mathrm{FEV} 1<25 \mathrm{~mL} \cdot \mathrm{yr}^{-1}$ was considered physiological [16]. As a substantial number of patients reached the outcome of interest, ORs were inappropriate to estimate relative risks; therefore, they were re-calculated into relative risks (RRs) [22].

\section{RESULTS}

Of the 136 patients enrolled in 1998 or 1999, 98 could be reassessed. Nine patients were lost to follow-up, nine did not consent, two had missing lung function data at baseline, 12 were too disabled by their asthma or concomitant diseases to participate in the follow-up visit, and six patients had died (one due to asthma and five due to comorbidity). There were

\begin{tabular}{|c|c|c|c|}
\hline \multirow[t]{3}{*}{ TABLE 2} & \multicolumn{3}{|c|}{$\begin{array}{l}\text { Relative risks for an accelerated decline }{ }^{\#} \text { in } \\
\text { forced expiratory volume in one second (FEV } 1 \text { ) in } \\
\text { all patients and in patients with baseline FEV1 } \\
\geqslant 80 \% \text { of the predicted value }\end{array}$} \\
\hline & & \multicolumn{2}{|c|}{ Patients } \\
\hline & & All & FEV $1 \geqslant 80 \%$ preo \\
\hline \multicolumn{2}{|c|}{ Age of asthma onset $\geqslant 15 \mathrm{yr}$} & $0.8(0.4-1.3)$ & $0.9(0.4-1.6)$ \\
\hline \multicolumn{2}{|c|}{ Duration of asthma $\geqslant 18 \mathrm{yr}$} & $1.0(0.6-1.5)$ & $0.8(0.3-1.4)$ \\
\hline \multicolumn{2}{|l|}{ Atopy } & $0.9(0.5-1.5)$ & $0.9(0.4-1.5)$ \\
\hline \multicolumn{2}{|c|}{$\mathrm{PC}_{20}$ histamine $\leqslant 1 \mathrm{mg} \cdot \mathrm{mL}^{-1}$} & $0.6(0.3-1.3)$ & $0.6(0.2-1.5)$ \\
\hline \multicolumn{2}{|c|}{ Blood eosinophils $\geqslant 0.45 \times 10^{9}$} & $1.3(0.7-2.0)$ & $2.0(0.9-2.6)$ \\
\hline \multicolumn{2}{|c|}{ Sputum eosinophils $\geqslant 2 \%$} & $1.6(0.8-2.5)$ & $2.0(0.8-2.8)$ \\
\hline \multicolumn{2}{|c|}{$\mathrm{FeNO} \geqslant 20 \mathrm{ppb}$} & $1.9(1.1-2.6)$ & $3.1(1.7-3.4)$ \\
\hline
\end{tabular}

Data are presented as relative risk (95\% confidence interval). PC20: provocative dose causing a $20 \%$ fall in $\mathrm{FEV}_{1}$; FeNO: the fraction of nitric oxide in exhaled air $\#: \geqslant 25 \mathrm{~mL} \cdot \mathrm{yr}^{-1}$.

no differences in baseline characteristics between participating and nonparticipating patients (table 1).

The median (range) follow-up interval was 5.7 (4.3-6.8) yrs. The median change in post-bronchodilator FEV1 was a decline of $12.6 \mathrm{~mL} \cdot \mathrm{yr}^{-1}$. An accelerated decline in FEV1 $\left(\geqslant 25 \mathrm{~mL} \cdot \mathrm{yr}^{-1}\right)$ was observed in $39 \%$ of the patients. The median (range) decline in FEV1 in these patients was $54.7(27.1-173.7) \mathrm{mL} \cdot \mathrm{yr}^{-1}$.

The median (range) dose of inhaled corticosteroids differed slightly between baseline and follow-up $(1,600(1,600-4,800)$ and 1,600 (0-12,800) $\mu \mathrm{g}$, respectively). There was no relationship between the change in corticosteroid dose and decline in FEV1, and no difference in the median dose of oral corticosteroids between baseline and follow-up.

\section{Association between potential predicting factors and decline in FEV1}

FEV1 and FeNO were (weakly) associated with decline in lung function (B 0.7, 95\% CI 0.1-1.3) and B 29.1, 95\% CI -6.5-64.7, respectively) when analyed as continuous independent variables. None of the other factors showed any association with decline in lung function. When using contrasts in variables, FeNO levels $\geqslant 20 \mathrm{ppb}$ were shown to be associated with an increased decline in FEV1 compared with FeNO levels $<20 \mathrm{ppb}$, with an excess decline of $40.3 \mathrm{~mL} \cdot \mathrm{yr}^{-1}$ in patients with $\mathrm{FeNO}$ $\geqslant 20 \mathrm{ppb}$ (B 40.3, 95\%CI 7.3-73.2). Further analysis showed that patients with $\mathrm{FeNO}$ values $\geqslant 20 \mathrm{ppb}$ had a $57 \%$ risk of an accelerated decline in FEV1 $\left(\geqslant 25 \mathrm{~mL} \cdot \mathrm{yr}^{-1}\right)$ compared with $30 \%$ in patients with an FeNO $<20 \mathrm{ppb}$ (RR 1.9, 95\% CI 1.1-2.6; table 2).

When investigating the interaction between baseline FEV1 and FeNO it appeared that baseline FEV1 modified the predictive effect of FeNO on decline in FEV1. Therefore, the decline in FEV1 was assessed in four separate groups, based on the level of $\mathrm{FeNO}(<20$ versus $\geqslant 20 \mathrm{ppb})$ and baseline FEV1 $(<80 \%$ versus $\geqslant 80 \%$ pred). Patients with both an FeNO $\geqslant 20 \mathrm{ppb}$ and an FEV1 $\geqslant 80 \%$ had the greatest decline in FEV1 (median decline (range) 43.5 (14.0-173.7) $\mathrm{mL} \cdot \mathrm{yr}^{-1}, \mathrm{p}=0.003$ (Kruskall Wallis); 

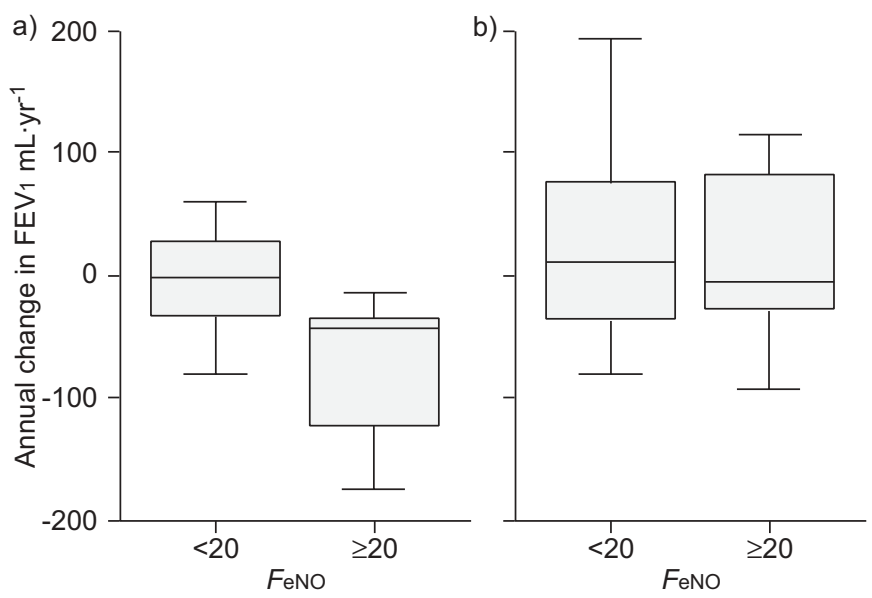

FIGURE 1. Annual change in forced expiratory volume in one second ( $\left.F E V_{11}\right)$ after maximal bronchodilation in patients with fraction of nitric oxide in exhaled air ( $\mathrm{FeNO}$ ) $<20$ or $\geqslant 20 \mathrm{ppb}$ and a) FEV $1 \geqslant 80 \%$ predicted and b) FEV $1<80 \%$ pred. Boxes represent the median and 25th-75th percentiles, and whiskers represent the range.

fig. 1). In patients with normal baseline FEV1 ( $\geqslant 80 \%$ pred), but not in those with baseline FEV1 $<80 \%$ pred, there was a relationship between FeNO and decline in FEV1 (B 72.5, 95\% CI 39.5-105.6). A 10-fold increase in FeNO was associated with an additional decline in FEV1 of $72.5 \mathrm{~mL} \cdot \mathrm{yr}^{-1}$ (fig. 2). Among patients with a baseline FEV1 $\geqslant 80 \%$ pred, those with an FeNO $\geqslant 20 \mathrm{ppb}$ had a $90 \%$ risk of accelerated decline in FEV1 compared with $29 \%$ in those with FeNO $<20$ ppb (RR 3.1, 95\% CI 1.7-3.4; table 2).

\section{DISCUSSION}

The present multicentre 5-yr follow-up study of 136 patients with difficult-to-treat asthma shows that high FeNO levels predict accelerated decline in lung function. There was no association between decline in lung function and other potential predicting factors, except for baseline FEV1. Patients with an FeNO $\geqslant 20 \mathrm{ppb}$ (despite high doses of inhaled or oral corticosteroids) and FEV1 within normal limits had a 3.1-fold risk of accelerated decline in lung function over the following 5 yrs. Elevated levels of FeNO in patients with difficult-to-treat asthma might reflect an as yet undetermined injurious process in the airway wall, which is relatively unresponsive to high doses of inhaled and/or oral corticosteroids, and eventually leads to loss of lung function.

FeNO is a marker of asthma that is increasingly recognised as a valuable tool in clinical practice for diagnosing and guiding treatment [23]. This noninvasive test is easy to perform, reproducible, safe and well tolerated, even in patients with severe asthma. FeNO levels are increased in asthma [24], are associated with other markers of lower airway inflammation [25] and decrease in a dose-dependent manner with antiinflammatory therapy [26]. There are, however, patients with asthma in whom $F$ eNO levels remain high, despite corticosteroid treatment $[27,28]$. The present study shows that FeNO $>20$ ppb is a predictor of a more rapid decline in FEV1 in these patients.

In the present study, several clinical and inflammatory parameters were considered as potential predictors, but the results
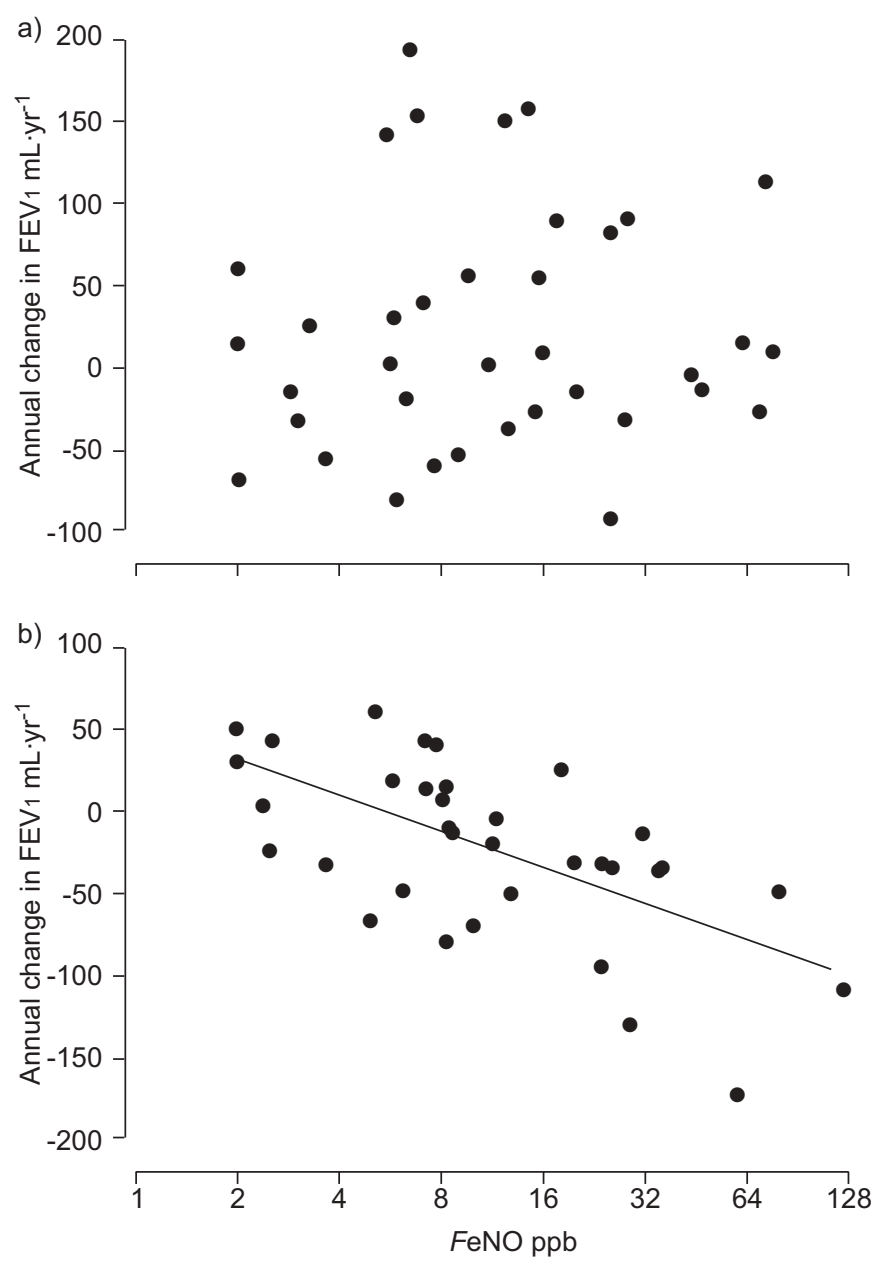

FIGURE 2. Relationship between annual change in forced expiratory volume in one second (FEV 1$)$ after maximal bronchodilation and baseline fraction of nitric oxide in exhaled air $\left(F_{\mathrm{eNO}}\right)$ in a) patients with baseline $\mathrm{FEV}_{1}<80 \%$ pred and $\mathrm{b}$ ) patients with baseline FEV $1 \geqslant 80 \%$ pred $(r=-0.62, B=-72.5 ; p<0.01)$.

showed that only elevated FeNO levels were associated with accelerated lung function decline. This differs from previous studies in the overall asthma population that have shown associations between the rate of lung function decline and a short duration of asthma, nonatopic status and bronchial hyperresponsiveness [29]. The current results also differ from those of cross-sectional studies in patients with chronic severe asthma showing associations of eosinophilia in blood [10], sputum [3] and bronchial biopsy [11] with persistent airflow limitation. This can be explained by differences in the asthma populations being studied (severe as opposed to mild), or by differences in study design (longitudinal as opposed to crosssectional). An alternative explanation for the discrepancy between the current findings and previous studies might be that some potential risk factors, such as sputum eosinophilia and airway hyperresponsiveness, could not be assessed in all the patients with difficult-to-treat asthma, which might have affected the power of the study with respect to these factors. However, the correlation coefficient between sputum eosinophils and lung function decline in the present study was only 0.09. A sample size of $>1,000$ patients would have been needed in order to have 
obtained statistical significance with this very low correlation coefficient, which is probably not clinically relevant.

The present study may have some limitations. First, the decline in FEV1 was based on only two measurements, with an interval of 5 yrs. Although several lung function measurements have been performed in different clinics during these $5 \mathrm{yrs}$, they were not standardised with respect to equipment, premedication and asthma control, and therefore of no use for this study. For the two study visits, every effort was made to measure FEV1 with the same lung function equipment, after the same doses of inhaled salbutamol and ipratropiumbromide, and during a period of stable disease, for maximal comparability. Additionally, the choice of cut-off points for dichotomising the potential risk factors used in the analysis might be criticised. However, all cut-off points were either based on median values (age at asthma onset, asthma duration and FEV1), local normal values (blood eosinophils), recommendations from epidemiological studies (airway responsiveness and sputum eosinophils) or, in the case of FeNO, on ROC analysis.

How can the main findings of the present study be explained? There is increasing evidence that NO contributes to airway damage, inflammation and remodelling. In asthma, exhaled nitric oxide is mainly derived from the intrapulmonary airways. It is synthesised by constitutive and inducible NO synthases (iNOS) using L-arginine as a substrate. Airway inflammation promotes iNOS expression as well as superoxide production, interacting with $\mathrm{NO}$ to form the potent oxidant peroxynitrite [30]. Long-term persistence of this "nitrosative stress" induces cell injury and may also contribute to steroid resistance. Interestingly, inflammation-induced increase in arginase activity promotes local polyamine synthesis [30], which could induce airway remodelling, and eventually lung function decline in asthma.

Elevated levels of FeNO in patients with severe asthma despite corticosteroid treatment were observed. This might point towards inflammatory processes in the airways that are steroid resistant, or to insufficient doses of anti-inflammatory medication at the site of inflammation. iNOS, produced by primary human epithelial cells, is indeed not steroid sensitive [31], and severe airway inflammation may overcome the effects of steroids on iNOS expression [30]. Another possibility is that iNOS is produced in regions of the airways that are not, or barely, accessible to inhaled corticosteroids, such as the peripheral airways, or that the patients were not compliant with corticosteroid treatment. Although this latter possibility cannot be fully excluded, it is highly unlikely, as elevated FeNO levels have been observed in several other clinical trials where asthmatic adults receiving inhaled or oral corticosteroids were carefully evaluated [27, 28]. Taken together, iNOS expression was not sufficiently suppressed by corticosteroids, either because of (relative) corticosteroid insensitivity or inadequate steroid dosing.

The present study may have implications for clinical practice and future research. The current results suggest that FeNO can identify patients at risk of accelerated lung function decline at an early, "silent" stage of the disease. Importantly, these patients cannot be distinguished from other patients with difficult-to-treat asthma on clinical grounds or on the basis of lung function criteria. Therefore, it might be useful to include
FeNO measurements in the assessment of patients with difficult-to-treat asthma, in order to identify those who are at risk of poor asthma outcome and those who might be eligible for novel asthma treatment or individualised treatment strategies [5, 23]. However, further confirmation of the present results is needed in a prospective follow-up study that contains a series of standardised lung function measurements over time.

In conclusion, the present authors have demonstrated that elevated levels of exhaled nitric oxide fraction predict an accelerated decline in forced expiratory volume in one second in patients with difficult-to-treat asthma, particularly if lung function is still normal. Elevated levels of exhaled nitric oxide fraction in these patients might reflect ongoing damage to the airways, and the current findings warrant further study of the mechanisms of this injurious process, which is relatively unresponsive to high doses of inhaled and/or oral corticosteroids.

\section{ACKNOWLEDGEMENTS}

The authors would like to thank M.C. Timmers (Dept of Pulmonology, Leiden University Medical Centre, Leiden, the Netherlands) for technical assistance, and the pulmonologists of the participating hospitals in the Netherlands for their cooperation: P.I. van Spiegel and G. Visschers (Slotervaart Hospital, Amsterdam); A.H.M. van der Heijden and C.H. Rikers (Rode Kruis Hospital, Beverwijk); B.J.M. Pannekoek (Reinier de Graaf Gasthuis, Delft); H.H. Berendsen, K.W. van Kralingen and J. van den Berg (Bronovo Hospital, Den Haag); H.G.M. Heijerman and A.C. Roldaan (Leyenburg Hospital, Den Haag); A.H.M. van der Heijden (Spaarne Hospital, Heemstede); H.C.J. van Klink (Diaconessenhuis, Leiden); C.R. Apap (St. Antoniushove, Leidschendam); A. Rudolphus and K.Y. Tan (St. Franciscus Gasthuis, Rotterdam).

\section{REFERENCES}

1 Wenzel S. Severe asthma in adults. Am J Respir Crit Care Med 2005; 172: 149-160.

2 Lange P, Parner J, Vestbo J, Schnohr P, Jensen G. A 15-year follow-up study of ventilatory function in adults with asthma. N Engl J Med 1998; 339: 1194-1200.

3 ten Brinke A, Zwinderman AH, Sterk PJ, Rabe KF, Bel EH. Factors associated with persistent airflow limitation in severe asthma. Am J Respir Crit Care Med 2001; 164: 744-748.

4 Hansen EF, Phanareth K, Laursen LC, Kok-Jensen A, Dirksen A. Reversible and irreversible airflow obstruction as predictor of overall mortality in asthma and chronic obstructive pulmonary disease. Am J Respir Crit Care Med 1999; 159: 1267-1271.

5 Heaney LG, Robinson DS. Severe asthma treatment: need for characterising patients. Lancet 2005; 365: 974-976.

6 Pascual RM, Peters SP. Airway remodeling contributes to the progressive loss of lung function in asthma: an overview. J Allergy Clin Immunol 2005; 116: 477-486.

7 Holgate ST, Holloway J, Wilson S, et al. Understanding the pathophysiology of severe asthma to generate new therapeutic opportunities. I Allergy Clin Immunol 2006; 117: 496-506. 
8 Bai TR, Vonk JM, Postma DS, Boezen HM. Severe exacerbations predict excess lung function decline in asthma. Eur Respir J 2007; 30: 452-456.

9 van Rensen EL, Sont JK, Evertse CE, et al. Bronchial CD8 cell infiltrate and lung function decline in asthma. Am J Respir Crit Care Med 2005; 172: 837-841.

10 Bumbacea D, Campbell D, Nguyen L, et al. Parameters associated with persistent airflow obstruction in chronic severe asthma. Eur Respir J 2004; 24: 122-128.

11 Miranda C, Busacker A, Balzar S, Trudeau J, Wenzel SE. Distinguishing severe asthma phenotypes: role of age at onset and eosinophilic inflammation. J Allergy Clin Immunol 2004; 113: 101-108.

12 ten Brinke A, van Dissel JT, Sterk PJ, Zwinderman AH, Rabe KF, Bel EH. Persistent airflow limitation in adultonset nonatopic asthma is associated with serologic evidence of Chlamydia pneumoniae infection. J Allergy Clin Immunol 2001; 107: 449-454.

13 ten Brinke A, Sterk PJ, Masclee AA, et al. Risk factors of frequent exacerbations in difficult-to-treat asthma. Eur Respir J 2005; 26: 812-818.

14 Chung KF, Godard P, Adelroth E, et al. Difficult/therapyresistant asthma: the need for an integrated approach to define clinical phenotypes, evaluate risk factors, understand pathophysiology and find novel therapies. ERS Task Force on Difficult/Therapy-Resistant Asthma. European Respiratory Society. Eur Respir J 1999; 13: 1198-1208.

15 Kharitonov S, Alving K, Barnes PJ. Exhaled and nasal nitric oxide measurements: recommendations. The European Respiratory Society Task Force. Eur Respir J 1997; 10: 1683-1693.

16 Quanjer PH, Tammeling GJ, Cotes JE, Pedersen OF, Peslin R, Yernault JC. Lung volumes and forced ventilatory flows. Report Working Party Standardization of Lung Function Tests, European Community for Steel and Coal. Official Statement of the European Respiratory Society. Eur Respir J 1993; 6: Suppl. 16, 5-40.

17 Sterk PJ, Fabbri LM, Quanjer PH, et al. Airway responsiveness. Standardized challenge testing with pharmacological, physical and sensitizing stimuli in adults. Report Working Party Standardization of Lung Function Tests, European Community for Steel and Coal. Official Statement of the European Respiratory Society. Eur Respir J 1993; 6: Suppl. 16, 53-83.

18 ten Brinke A, de Lange C, Zwinderman AH, Rabe KF, Sterk PJ, Bel EH. Sputum induction in severe asthma by a standardized protocol: predictors of excessive bronchoconstriction. Am J Respir Crit Care Med 2001; 164: 749-753.

19 Cockcroft DW, Murdock KY, Berscheid BA, Gore BP. Sensitivity and specificity of histamine PC20 determination in a random selection of young college students. J Allergy Clin Immunol 1992; 89: 23-30.

20 Belda J, Leigh R, Parameswaran K, O’Byrne PM, Sears MR, Hargreave FE. Induced sputum cell counts in healthy adults. Am J Respir Crit Care Med 2000; 161: 475-478.

21 Olivieri M, Talamini G, Corradi M, et al. Reference values for exhaled nitric oxide (reveno) study. Respir Res 2006; 7: 94.

22 Zhang J, Yu KF. What's the relative risk? A method of correcting the odds ratio in cohort studies of common outcomes. JAMA 1998; 280: 1690-1691.

23 Taylor DR, Pijnenburg MW, Smith AD, de Jongste JC. Exhaled nitric oxide measurements: clinical application and interpretation. Thorax 2006; 61: 817-827.

24 Kharitonov SA, Yates D, Robbins RA, Logan-Sinclair R, Shinebourne EA, Barnes PJ. Increased nitric oxide in exhaled air of asthmatic patients. Lancet 1994; 343: 133-135.

25 Berlyne GS, Parameswaran K, Kamada D, Efthimiadis A, Hargreave FE. A comparison of exhaled nitric oxide and induced sputum as markers of airway inflammation. $J$ Allergy Clin Immunol 2000; 106: 638-644.

26 Kharitonov SA, Donnelly LE, Montuschi P, Corradi M, Collins JV, Barnes PJ. Dose-dependent onset and cessation of action of inhaled budesonide on exhaled nitric oxide and symptoms in mild asthma. Thorax 2002; 57: 889-896.

27 Silkoff PE, Lent AM, Busacker AA, et al. Exhaled nitric oxide identifies the persistent eosinophilic phenotype in severe refractory asthma. J Allergy Clin Immunol 2005; 116: 1249-1255.

28 Stirling RG, Kharitonov SA, Campbell D, et al. Increase in exhaled nitric oxide levels in patients with difficult asthma and correlation with symptoms and disease severity despite treatment with oral and inhaled corticosteroids. Asthma and Allergy Group. Thorax 1998; 53: 1030-1034.

29 Ulrik CS. Outcome of asthma: longitudinal changes in lung function. Eur Respir J 1999; 13: 904-918.

30 Ricciardolo FL, Sterk PJ, Gaston B, Folkerts G. Nitric oxide in health and disease of the respiratory system. Physiol Rev 2004; 84: 731-765.

31 Donnelly LE, Barnes PJ. Expression and regulation of inducible nitric oxide synthase from human primary airway epithelial cells. Am J Respir Cell Mol Biol 2002; 26: 144-151. 